\title{
Grounds for protest: placing Shwedagon pagoda in colonial and postcolonial history
}

\author{
PENNY EDWARDS*
}

In November 1885, Britain exiled the Burmese King Thibaw and Queen Suppayalat to Ratnagari in western India, and so secured Burma's annexation as a province of India. Their forced flight inspired a popular nationalist song, Partamu (Exile), whose lyrics equated colonial occupation with religious dislocation, and condemned the British for denying the royal couple their parting wish to visit Burma's most sacred Buddhist image, the Mahamuni statue near the royal capital of Mandalay. The exile of Thibaw and Suppayalat dethroned the monarchy as an institution along with its incumbents, transferring political power to a Christian dominion. Previous dynastic change had seen the uninterrupted sponsorship of Buddhist learning and heritage by Mon and Burman monarchs. Rather than exploit this vacuum by attempting to assume the mantle of a Dhammaraja (righteous ruler) through the support of monasteries and pagodas, Britain inaugurated its rule through acts of desecration and the appropriation and militarization of sacred space. Focusing on the sacred site of the Shwedagon hpaya (pagoda) in Rangoon, this article explores these processes from the first AngloBurmese war of 1824 to Independence in 1947, and their postcolonial ramifications.

The most magnificent structure in Rangoon, Shwedagon pagoda contains a reliquary stupa believed to hold hairs from the head of Gotama Buddha. Its gleaming golden dome forms the spiritual core of a constellation of smaller shrines ranged across its terrace and on the slopes of Singattura hill. The singular essence of the stupa and quotidian devotional activity lends the pagoda complex a sacral aura, such that Shwedagon might be said to epitomize the sanctuary spaces of Buddhism in Burma-spaces that have historically included both the physical sanctum of pagoda precincts and the spiritual refuge of vipassana meditation. The $h t i$, or finial, of Shwedagon is more symbolic of temporal power, and its erection, embellishment and replacement has long marked the establishment of sovereignty over the delta. During the colonial period, competing claims to this sanctuary space made Shwedagon a natural arena for anti-colonial protests. This spiritual and temporal significance, coupled with the pagoda's history of resistance to foreign domination, secured Shwedagon's status as 'a palladium of the Burmese nation-state'. ${ }^{1}$ A major leitmotiv in Burmese nationalist song and 
literature of the 1910s to 1940s, Shwedagon also figures in the religious sentiments and national imaginaries of numerous groups, notably the Mon, for whom it remains a major site of pilgrimage.

Against these histories, my aim here is not to examine Shwedagon as an exemplar of the Burmese nation. Rather, my interest lies in what Shwedagon's multiplex history can tell us about larger issues relating to the appropriation of both space (the pagoda precinct) and time (the past, or competing versions of the past, enshrined and inscribed therein). Unlike the rare artefacts that are the stock-in-trade of museum collections and art dealerships, the value of Shwedagon lies not in its portability or its ability to augment the wealth or spiritual powers of any single art collector or cultural institution, but rather in its potential to augment or validate claims to authority by political elites. Building on a growing corpus of scholarship about the way in which historiography and museology are fused in what I here dub the museography of Myanmar, ${ }^{2}$ and drawing on colonial archival materials, this article sheds new light on nineteenth- and twentieth-century strategies to violate, subjugate and appropriate the Buddhist heritage and sanctuary spaces of Shwedagon.

\section{Buddhist and Christian perspectives on building merit}

The centrality of temples as vectors of past belief and practice in Burma is reflected in the Burmese term for history, thamaing, which denotes the sacred history of a shrine. ${ }^{3}$ We see a modern example of this formulation in the preface to a 1949 history of Shwedagon, whose author describes its publication as a work of merit. ${ }^{4}$ Here it is helpful to think in terms of Juliane Shober's distinction between rupakaya, or the material body of the Buddha identified with his relics, and thus incorporating stupas, images and other such sacred objects, and the Dhammakaya, or the body of the Buddha's teachings. ${ }^{5}$ The fusion of spiritual potency and the material environment in rupakaya resonates in the Burmese term hpaya, which, like the Mon term kyaik, denotes both the Buddha and pagoda. ${ }^{6}$ While the Dhamma is eternal, as one prominent British Buddhist noted on visiting Shwedagon on the eve of Independence, 'forms need constant renewal'. 7 From the fourteenth century onward, Shwedagon underwent repeated renovation; new layers were rebuilt over the reliquary nucleus, accompanied by the insertion of precious gems, small Buddha images and meritorious objects such as bells, into the new layers. Shwedagon's sacrality attracted a perpetual renewal that was atypical of Burma's broader monumental landscape. More commonly, the greater joy and kammic dividends of starting a new image or edifice rather than repairing an existing monument encouraged the erection of new forms alongside older, crumbling stupas. In Burma the title 'Stupa Builder' is an honorific. ${ }^{8}$

Buddhist monarchs sponsored temple construction and renovation to glorify the power of the present, to channel merit to their ancestors, and to invest in their future fortunes and those of their kingdom. These devotional acts, when conducted on a large scale such as King Mindon's renovations of Shwedagon in 1871, allowed community participation and contingent merit generation through donations of gold, jewels, money, and voluntary labour. 
The rupakaya thus offered avenues of merit-making across a broad social spectrum. Wealthy patrons could sponsor new shrines or prayer halls at Shwedagon; those of moderate means could fund exterior decor; while individuals could garner merit by attaching gold leaf to images; and those of little or no means could volunteer their services for the construction or upkeep of religious buildings. Merit can also be gained through the physical exertion of ascending the hill to Shwedagon. In carrying out meritorious acts, personal deportment is paramount. The language of Buddhist devotion is inscribed into bodily practice, ranging from the raising and joining of one's palms and the bowing of the head on facing a Buddha image, to removing shoes and other foot coverings before entering a pagoda. Such practices were generally ignored by Europeans.

Western perceptions of Shwedagon changed over time. Where, in 1538, a Venetian jeweller delighted in the gilding, gardens, monks and stalls at Shwedagon, in 1795 Captain Symes, a British Envoy to the Court of Ava, focused on the width and breadth of the roads leading to the temple, its height and the surrounding presence of or potential locations for stockades, canons, musketeers and bridges. ${ }^{9}$ Where British military officers seized on Shwedagon's strategic potential, Christian missionaries saw it as a heathen stronghold whose magnificence epitomized Protestant notions of Oriental decadence, and so symbolized obstacles to the expansion of Christianity in Burma. Sights like this, wrote the young American missionary Anna Judson in 1813 , 'fire the soul with an inconquerable desire to make an effort to rescue this people from destruction'. ${ }^{10}$ The disconcerting similarities between Shwedagon's 'polished spires' and American church steeples left Judson struggling to place the psychological distance her conscience dictated between such Eastern 'monuments of idolaters!' and Christian meeting houses. In asserting such distance, she and other missionaries and colonials turned from the shape of stupas to their substance-gold and glittering glass or jewelled inlay - as the inversion of such Christian virtues as 'thrift'. The Burman, stated one observer, is apt to 'dissipate' any surplus 'in works of religious merit, such as the building of a Pagoda or Zayát [rest house]'. ${ }^{11}$ Such investment in the material environment fell foul of Protestant notions of frugality and modesty. Christian feelings of distance and disdain for Buddhism were further heightened by the social atmosphere of visits to the temple, where laughter and conversation were construed as a 'spirit of carnival', and the lack of 'any regular service' encouraged mistaken notions that the Burmese lacked any sense of 'sanctity' vis-à-vis 'temples and religious edifices'. ${ }^{12}$ This trivialization of Buddhist monuments coloured Rudyard Kipling's poem The Road to Mandalay (1888), which reduced the rupakaya at Moulmein's historic pagoda to a 'Bloomin' idol made o' mud - / Wot they called the Great Gawd Budd'. ${ }^{13}$

Although Shwedagon is popularly promoted as a Burmese Buddhist monument, the ethnic diversity, origins and identifications of its pilgrims indicate a far more complex genealogy. This complexity is reflected in the daily devotional activity at Shwedagon to the spirits that rule one's birthday, and in the role of the King of the Nagas and four Nats (spirit guardians) in 
the foundational legend of Shwedagon. Historian Emmanuel Guillon reads this legend as the 'distant echo of a pre-Buddhist chthonic cult' at the Singattura hill on which Shwedagon stands. After the establishment of the reliquary at Shwedagon, the sanctuary appears to have lain fallow for some seven centuries, indicating an abandonment of this cult. ${ }^{14}$ It was not until the fourteenth century, when the site became incorporated into the fiefdoms of Mon Queens, that Shwedagon underwent successive restorations, as 'each royal generation' of the Kingdom of Pegu contributed to its embellishment. From 1459 to 1469, Queen Shinsawbu elevated the stupa to 129 feet, terraced the hill, and assigned land and hereditary slaves in perpetuo for its upkeep. By 1768, further additions had raised the height of Shwedagon to 321 feet. To the Mons, Shwedagon was never the palladium of the kingdom (a role played by a treasure), but it was 'the sacred place'. ${ }^{15}$ In 1774, King Sinpyushin marked the final Burman conquest of Pegu by replacing the hti, formerly in the Mon style, with a finial in the 'Burman style' and re-gilding the pagoda from pinnacle to base. Intended to symbolize the 'complete Burmanizing' of Mon country, this act of dedication was also an act of legitimization, sealing royal conquest with divine sanction. As art historian Elizabeth Moore notes, donation to the Shwedagon by royal or central authority has always marked 'control of the delta' and 'rule of the country'. ${ }^{16}$ However, the demerits of erasing pre-existing Buddhist structures ensured that monuments to Mon rulers, such as King Dhammazedi's fifteenth-century inscriptions narrating the founding legend and successive donations to Shwedagon in Mon, Burmese and Pali, survived these political ruptures.

\section{The militarization of Shwedagon, 1824-1852}

When Britain declared war on the Court of Ava in 1824, frontline troops swarmed into the pagoda. For the next six months, the history of the first Anglo-Burmese war was 'more or less the history of the paya [pagoda]'. ${ }^{17}$ The impressive surveillance and cover offered by Singattura hill, the vast pagoda platform, and its many terraces and shrines made Shwedagon the ideal base for a fortress, and the British used it to deadly effect against a large and courageous, but poorly equipped, Burman army, who were forced to retire after several assaults and heavy casualties. ${ }^{18}$ While cross-fire scarred the Shwedagon, the greatest toll was exacted by British troops who ransacked countless shrines in search of silver and gilt Buddha images which were then sold onward to Calcutta. ${ }^{19}$ 'It was truly melancholy to observe the ravages [...] on smaller pagodas surrounding the Shwedagon; one alone, amongst thousands, was preserved from the pillage', wrote one observer. ${ }^{20}$ Among the carpet-baggers was Captain Frederick Maryatt, whose spoils included 'a Burmese shrine with silver idols'. ${ }^{21}$ In 1826, King Bagyidaw signed a treaty ceding lower Burma to the British, and so saved Rangoon. Five years later, Bagyidaw reasserted his sovereignty by gilding the Shwedagon hpaya.

In 1852, Shwedagon again came under military occupation in the second Anglo-Burmese war. The first architectural casualty was the covered walkway down the hill, which had been constructed by Ma May Gale, Queen of King 
Tharawaddy. ${ }^{22}$ Looting was endorsed by General Campbell, who supervised the digging of a large pit. Another commanding officer, Frazer, led a search for the precious relics enshrined in the pagoda. Both men entered Burmese lore as caricatures of colonial depredation. ${ }^{23}$ The Illustrated London News showed victorious British troops, in their red uniforms and gilt, weapons in hand, standing about the pagoda. ${ }^{24}$ Voicing popular outrage, the senior monk U Htaw Lay wrote letters of protest to Lord Dalhousie, who ordered a stop to the 'destruction of Buddhist statues' by 'our soldiers', both to assuage Burmese anger and to end the disgrace of 'our people'. U Htaw Lay was subsequently appointed Trustee of Shwedagon.

The military occupation of Shwedagon generated detailed internal correspondence. In December 1853, the Deputy Secretary of the Governor General of India advised that 'on every grounds, political and military, the pagoda ought to be retained as a fortified position'. Burmese would be admitted to the pagoda only through the southern entrance, and only on stated feast days; all other entrances would remain closed for military use. Ammunition stocks for the whole of Pegu would be based at the pagoda's western side, with 'Ordnance buildings [...] artillery' and barracks close at hand. A wall with embrasures for guns and loopholes for musketry would be built across the pagoda platform from east to west, and a rail-track laid on the northern slope to relay military supplies. In a bid to prevent the recurrence of the 'frequent' and 'regrettable' attempts to dig into the pagoda, and to allay the anxieties of the Burmese people, Captain Phayre recommended the restitution of servants to care for the pagoda, provided they were 'few in number', 'recorded by name', 'subject to visits by our officers' and 'subject to due control'. He further ordered the demolition of all 'the ruined buildings which remain on the second and on the lowest platforms', and the official closure of 'all areas from the southern entrance to the second platform'. ${ }^{25}$

In Burma as elsewhere in empire, this desecration of indigenous spaces corresponded with a parallel sacralization of colonial heritage. As in India, fallen soldiers and missionary establishments were marked by tombs, monuments, churches, tablets and inscriptions celebrating the "martyrdom, sacrifice and ultimate triumphs of military and civilians whose death made sacred, to the Victorian Englishmen, their rule'. ${ }^{26}$ These processes coincided at Shwedagon, where English servicemen who had lost their lives in 1852 were interred on the main pagoda platform. ${ }^{27}$ This careful handling of Britain's war dead proceeded in parallel with the excision of precious gem-stones from the corpses of countless Burmese soldiers. ${ }^{28}$ Some forty years later, a group of British visitors to Shwedagon marvelled at this 'group of plain tombstones' whose English inscriptions commended 'the dead lying there to God'. These military graves entered the colonial imaginary as shrines to British gallantry. ${ }^{29}$

By the late nineteenth century, mosques, Chinese, Hindu and Sikh temples, Christian churches and a synagogue studded the urban landscape of Rangoon and Mandalay. Shwedagon's constituency, and the sponsors of its shrines, included Indians, Shans, Muslims, Burmese and Chinese. While American and European observers felt threatened or alienated by Burmese 
temple architecture, King Mindon (1853-1878) proved more tolerant of other creeds, and sponsored construction of a church, vicarage and missionary school in Mandalay. ${ }^{30}$ Struck by his 'liberality', Queen Victoria donated a font to the church. ${ }^{31}$ Meanwhile, a senior monk in Rangoon, U Pya, observing the disrepair of Shwedagon's finial and perhaps seeking to shore up the power of the monarchy, received permission from the British authorities to appeal to King Mindon to erect a new hti at Shwedagon. Mindon was quick to respond and, in 1871, presented a new jewelled and gilded $h t i{ }^{32}$ Fearing a crisis of legitimacy and the kindling of 'religious fanaticism' and national sentiment if Mindon raised the $h t i$, but mindful of the consequences of banning such a ceremony, the British forced a compromise. Mindon was allowed to send the hti down river, but British officials intercepted the hti on its arrival in Rangoon. At a ceremony attended by thousands, the Chief Commissioner oversaw its hoisting, thereby partially channelling merit and power to the Empire. ${ }^{33}$ Britain had gained a petty victory, but had also lost its sure Christian footing in Burma by gaining a political stake in the Buddhist cosmological system. On learning that the Chief Commissioner had 'assisted in putting up' his 'Royal gift', King Mindon was quick to authorize a more formidable display of royal power, commanding that the pagoda be gilded in its entirety in February 1872 with gold donated by him. Perhaps to keep the Chief Commissioner in check, Mindon enlisted the assistance of various Burmese notables, merchants and elders in Rangoon for this task, entrusting them with a shipment of gold leaf. ${ }^{34}$ In the space of fifty years, Britain's relationship with the Shwedagon pagoda had shifted from an aggressive strategic and acquisitive role to a more complex dynamic whereby the fate of British rule had become materially and symbolically intertwined with that of Shwedagon.

\section{Conservation and confrontation, 1897-1922}

In the mid- to late nineteenth century, the Burmese restoration of pagodas continued, often in the form of new brickwork, gilding and whitewash. ${ }^{35}$ In an apparently spontaneous reaction to the dislocation of British rule, and as a practical response to colonial despoliation at Shwedagon, hundreds of small shrines, rest-houses for pilgrims (zayats), and shelters traditionally used as gathering points by the public to listen to monks reciting the Dhamma (tazaungs) began to appear around the Shwedagon pagoda, providing an expanded sanctuary space but also an extreme irritant to colonial notions of aesthetic propriety. From the 1870s onward, individuals sponsored numerous works of merit, including zayats, along the walkways to replace those damaged in the 1852 war. ${ }^{36}$ In 1897, an English visitor to Burma blamed 'the religious enthusiasm of the pious' for 'structural additions' that 'seriously impaired the beauty' of Shwedagon. Calling for government intervention 'to guide the enthusiasm of present-day devotees', he argued that European artistic appreciation was needed to restore and protect 'the best examples of native art' ${ }^{37}$ This was not a lone voice, but signalled a general shift towards conservation. 
This softening of Britain's confrontational stance to Burmese monumental space reflected a transition from an intense phase of conquest and military engagement to a period of bureaucratic consolidation. The movements of new human resources encouraged a greater permeation of metropolitan ideologies into the colonial theatre at a time when fears about the degeneration of British institutions, culture and racial 'stock' fed an atmosphere of cultural pessimism in the Metropole. Hybridity became a key focus of cultural debate. ${ }^{38}$ The perceived need to segregate and conserve races and cultures focused attention on the role of monuments in the education of future generations, leading to the establishment of such heritage bodies as the National Trust. In this changed climate, Burmese heritage became increasingly romanticized in colonial accounts: 'ruined pagodas, temples and palaces' were now presented as a field ripe for European scholarship. ${ }^{3}$

These intellectual trends might have remained abstractions in the annals of colonial travellers had it not been for the resourcefulness and force of personality of two men: Taw Sein Ko, a Sino-Burmese civil servant who became Burma's first government archaeologist, and Lord Nathaniel Curzon. Both shared a late Victorian vision of conservation as a return to an authentic state of origin through the dismantlement or scraping back of paint, lacquer, gilding and other additions. They were also mindful of the political benefits of conservation, and Curzon would probably have subscribed to Taw Sein Ko's mistaken prediction that investment in this arena would shore up both the prestige and meritoriousness of Britain in the eyes of the Burmese population.

In 1901, the Viceroy of India, Lord Curzon, declared the need to 'safeguard for posterity the Great heritage of Burma'. Where earlier British rulers had belatedly cast their soldiers as the culprits of cultural destruction, this shift in policy stigmatized a new school of vandals: Burmese Buddhists armed with whitewash. ${ }^{40}$ Curzon's drive lent impetus to the work of Taw Sein Ko, much of whose initial thrust was aimed at the temples of Pagan and the palace of Mandalay. However, by asserting itself as the paramount custodian of the temples and the final arbiter of Buddhist construction projects, the Burma Archaeological Survey (BAS), an arm of the colonial administration, threatened both to encroach upon monastic power in general and to violate such sanctuary spaces as Shwedagon. Once monuments were listed by the BAS, further additions were vetoed. Such prescriptions contravened Theravadin conventions, threatening to erase the merit of the sponsors of past restorations, and to obstruct new works of merit by contemporary donors.

From 1900 on, the trustees of the pagoda called for subscriptions to cover Shwedagon's bulbous spire with gold plates, and the work commenced in $1903{ }^{41}$ A bill for the preservation of objects of archaeological and artistic interest in Burma was announced in the Gazette of India of 5 March 1904. New legislation forbade government funds for temple upkeep to be spent on gilding or on the performance of phwe (Burmese theatre), a popular field of merit generation. In 1905-1906, the Prince of Wales donated four such large gold plates while on a tour of Burma. Despite such gestures, Taw Sein Ko found it as hard to enforce the removal of new colonial additions, such as 
the Protestant church and Upper Burma club at Thibaw's former royal palace, whose presence and whitewashed interiors had first raised Curzon's ire, as he did to ensure that Burmese temple custodians respected the ban on gilding. Unsurprisingly, in light of these double standards of enforcement, monks and lay temple guardians protested that the conservation policy denied the fundamental Buddhist 'right' to earn merit by adding to 'the national pagoda', or Shwedagon. ${ }^{42}$

By 1913, the platform of Shwedagon was covered with 'modern shrines' whose lack of harmony with 'aesthetic canons' led to their description by one colonial commentator as dangerous 'acts of vandalism'. ${ }^{43}$ To another contemporary, their lavish gilding and fanciful ornamentation threatened 'the ultimate extinction' of Burmese art. ${ }^{44}$ Ruing the lost simplicity and dignity of Shwedagon, and ignoring the religious essence of these structures, another observer declared these 'petty shrines' to be artistically void and thus 'wholly unnecessary'. ${ }^{45}$ Such aesthetic evaluations bristled with a loathing of hybridity in its racial, cultural and temporal forms. The confluence of Western modernity and Oriental antiquity evoked particular anxiety. In 1897, one observer sneered at a shrine at Shwedagon where images of Gotama Buddha and gaudy prints of the German Emperor and of the Madonna 'jostled promiscuously'. ${ }^{46}$ Soon after, another warned of the 'corruption' and 'decadence' at Shwedagon, declaring that contact with English and Indian influences had 'degraded' Burmese art, and denouncing 'cast-iron imitations of Burmese carving' from a Glasgow foundry as 'sacrilegious'. Thirkell-White grieved at the installation of electric lights at Shwedagon. ${ }^{47}$ While they balked at such juxtaposition, the same observers apparently saw no contradiction in the Christian burial of British soldiers in the grounds of Shwedagon, or the conversion of pagoda grounds in Mandalay to tennis courts. Similarly, while castigating cross-cultural experimentation by Burmese artisans, British observers 'boasted' of such additions to the landscape as a large bronze statue of Arthur Phayre. ${ }^{48}$ The language of such aesthetic critiques revealed a near pathological despair at the blurring of cultural borders: 'ugly gingham' replacements of bright paper parasols were a 'cruel sacrifice to economy', cigar cases of 'western shapes' symbolized 'decadence', and 'decadent toilet seats' evidenced 'debasing utilitarian propaganda'. ${ }^{49}$

'Our great object in antiquarian matters', reasoned Taw Sein Ko in 1910, 'is to conserve the ancient materials that are left to us, and not to create new types, forms or designs.' This philosophy was decried by religious elders and young nationalists as a threat to religion. ${ }^{50}$ In 1915 , the publication of Taw Sein Ko's list of protected monuments in the Burma Gazette 'roused the religious susceptibilities' of the Buddhist population and 'provoked objections against the monuments being declared protected'. To defuse popular outrage, the Local Government withdrew all such notifications in 1915. Shwedagon remained a barometer of architectural decline to such observers, but to Burmese nationalists the decline of the British government was uppermost. In 1916, lobbying by the Young Men's Buddhist Association and the All Burma Conference of Buddhists to enforce the removal of shoes on entering pagodas, a practice steadfastly resisted by Europeans, exacerbated the debate about 
colonial trespass on sacred space. In this fraught climate, Taw Sein Ko retired. Mindful of popular antipathy to the conservation law, his successor Charles Duroiselle decided against attempting to revive the 1915 list. ${ }^{51}$

In this battle of aesthetic appropriation, Britain failed to dictate the style of Burmese religion or to enforce its notions of heritage management on this site. The Burmese repudiation of aesthetic intrusion at Shwedagon appears to vindicate Partha Chatterjee's notion of religion as a place of refuge and a site for psychological resistance against colonial control. ${ }^{52}$ Attempts to police this sanctum saw a sustained military presence at the site from 1852 to 1930.

\section{Occupying Shwedagon's sanctuary spaces}

In 1897, Shwedagon remained held by a guard of European troops. The railtrack was still operational, ordnance was stored on the northwest face, and the western stairway remained closed, due to the erection of fortifications and magazines. ${ }^{53}$ Recognizing that the pagoda would be the natural place of refuge in time of serious disturbance', a senior civil servant, writing in 1913, stressed the necessity of continued military control. The presence of British troops and armaments at Shwedagon from 1852 until 1930, and the constant threat of its reoccupation thereafter, was both a sustained insult to Burmese religious practices and a form of sustained psychological torment. ${ }^{54}$

The many tazaungs and zayats whose architecture so irked colonial commentators provided key assembly points for student meetings at Shwedagon. In 1920, students from Rangoon College made a northwestern zayat their base for protests against a 1920 University Law which ruled that Rangoon College would continue to operate under the jurisdiction of Calcutta University. A popular song by Saya Tin celebrated this spirit of defiance: 'We left the University which just taught us to have a colonial spirit/ We united at Shwedagon to oppose power.' The students were successful, forcing a revision of the statute, and, perhaps as a result, a heavy presence of police and military police remained centred on Shwedagon.

In November 1921, public antipathy to the presence of colonial forces at Shwedagon fuelled the rapid escalation of a disagreement between Burmese monks and a Burmese theatre contractor over seating at a phwe into an armed confrontation with Gurkhas and military police, in which one Burmese civilian was killed. When a British sergeant threw a bottle at the pagoda steps, he sparked a backlash of stone-throwing by Burmese monks and laity who had taken position in a northern zayat, causing some fifty military police armed with batons and kukris to charge the pagoda steps, attacking electric cables, slashing stalls and breaking articles. An inquiry into the incident, overseen by the eminent scholar-official J S Furnivall, found fault with the sergeant and the 'sudden and impulsive' breach of discipline by some, but otherwise complimented commanding officer Major Macdonald on the conduct of his men. Instead, Furnivall's report focused on monks who held an 'indignation meeting' and a Burmese who had misinterpreted his apprehension by police as a comment on his nationalist garb, as examples of public attitudes that could generate friction and place a serious strain on 
the machinery of government. Two months later, an apparently similar turn of events at another pagoda in Rangoon led a committee to conclude that a 'spirit of hooliganism' among younger monks presented a 'standing menace to the cause of Law and Order'. ${ }^{55}$

Despite such reservations, in 1928 the remains of British soldiers were disinterred and removed to a new site at Mingaladon. Shwedagon remained in military custody until a public reopening of the western stairway on 2 March 1930. Months later, the Thakin group of nationalists held a massive meeting at Shwedagon pagoda, and the anti-colonial Dobama Asayone (We Burmans) Association set up its headquarters near Shwedagon. ${ }^{56}$ In homage to the pagoda, their de facto national anthem, We Burmese (Do Bama), compared the current status of Burmese under colonialism to the "pinnacle of a diamond $\mathrm{Hti}$ that has been reduced to mere firewood'. ${ }^{57}$

After the outbreak of the Second World War in 1939, anxieties in 'Buddhist circles' prompted a Member of the House of Representatives to seek public assurance that the Shwedagon pagoda would not be used as a fortress. An internal memo noted that while the government had 'no intention' of using the pagoda for such purposes, it might be necessary to occupy it in the event of 'internal troubles'. ${ }^{58}$ In 1939, booted police stormed the Shwedagon to break up a meeting at the headquarters of the Dobama Asayone Association, unleashing a string of strikes and protests whose rallying cry was the defence of Burmese religion and resistance to foreign invasion. Soon after, the Japanese bombardments of Rangoon turned the zaungdan leading to Shwedagon into shelters for those left homeless by the wartime bombings. ${ }^{59}$

\section{Remilitarizing Shwedagon in postcolonial Burma}

Following Independence, Shwedagon was regilded from 1947 to 1948, to mark the return of sovereignty to Burmese rulers. ${ }^{60}$ By this time, Shwedagon's diverse constituency had reinscribed the monument with a plural genealogy. The main pagoda platform hosted shrines sponsored by Chinese merchants and Chinese merit associations, Kachins, and Indian individuals and government officials. In the first decades after Independence, Shwedagon consolidated its status as a national monument under Premier U Nu's Buddhist Socialism. In 1962, General Ne Win inaugurated a near halfcentury of military rule in Burma, but not until 1988 did domestic and international outrage at the state massacre of thousands of civilians in Rangoon and Mandalay focus state attention on a concerted campaign to politicize merit. Shwedagon has provided the primary arena for this policy. However, history has subverted these attempts to corral the pagoda's spiritual potency. In particular, Shwedagon's past as a locus of opposition to authority has gained new symbolic resonance, sparking two decades of contestation.

It was at Shwedagon in August 1988 that Aung San Suu Kyi first galvanized mass support for what she called 'the second struggle for national independence'. ${ }^{6}$ Shwedagon has since become the nucleus of a highly materialistic and elaborately choreographed platform of merit-cultivation by the ruling military, whose programme of 'Myanmafication' and 'museumification' 
attempts to elevate the state to a celestial sphere. In this new formulation, one attains merit and pays homage to Buddha by advancing the physical construction of Myanmar, the name officially adopted by the government in 1989 which has since become synonymous with the military regime. In April 1999, the government oversaw the complete renovation and rehoisting of the $h t i$ at Shwedagon and its first complete regilding since 1872, with cash, gold, jewellery and labour donated by civil servants and other members of the public.

In many respects - repression of freedom of speech, the imprisonment of dissenters, the restriction of freedom of association, and regime violence, to cite a few - the military regime bears a striking resemblance to the autocratic excess of British rule. Its approach to heritage management, however, differs markedly from the colonial model, and favours gilding and garish paint on even the most ancient temples, in keeping with the traditions of renovation that so irked colonial administrators. This approach to merit-making has earned criticism from archaeologists and art historians at home and abroad. By lavishing coats of fresh paint and glitter on old crumbling brick structures across the country, the military brazenly stamps its ownership on numerous ancient sites, effecting their 'reincarnation' as 'sites of new Buddhist infrastructure'. ${ }^{62}$

Were it not for the military's refusal to make a public apology for the massacre as demanded by some members of the sangha in 1990, we might read their stupa-building zeal as religious acts by individuals mindful of their severe breach of key Buddhist precepts. Instead of seeking public atonement, the government stressed its pure Burmese and devout Buddhist credentials and, in an uncanny colonial echo, displaced the blame onto a few undisciplined soldiers. ${ }^{63}$ In this context, the military's monopolization of merit-making so soon after its mass blood-letting has generated resentment and cynicism instead of the respect traditionally accorded to wealthy sponsors. 'This is supposed to be a multicolour TV but all I ever see is green and yellow', ran one 1990s jibe at the constant TV coverage of khaki-clad military officials making donations to members of the sangha. ${ }^{64}$

While King Thibaw's former palace in Mandalay now houses a military garrison, Shwedagon has escaped such occupation. However, mass media coverage of military visits to Shwedagon sends clear signals to the population about the de facto military custodianship and penetration of this holy site. In her work on contemporary Myanmar, Skidmore notes the disjuncture between government rhetoric about the centrality of religious institutions in the life of the nation, and the way in which these sanctuary spaces are suborned by the state. ${ }^{65}$ In the words of one Burmese poet writing four years before the 1988 massacre, Shwedagon is a symbol of loving kindness and a place of refuge in times of trouble where people can lessen suffering. ${ }^{66}$ Through its sponsorship of Buddhist buildings, the State Peace and Development Council (SPDC) materializes its claim to 'the proper and consistent promotion of the Sasana [Buddhist religion]' by allowing citizens and monks to 'share' in merit, but leave no place of physical refuge outside their strict parameters. ${ }^{67}$ 
This elaborate choreography of power centres on the rupakaya, a field of legitimacy-building denied Aung San Suu Kyi, whose prolonged detention has obstructed her participation in such material acts of merit generation. Rather, as Gustaaf Houtman and Schober show, Suu Kyi's power and spiritual potency draw on both her father, Aung San, the architect of Burmese Independence, and the broader body of Buddha's teachings, known as Dhammakaya. ${ }^{68}$

Where Aung San Suu Kyi can claim continuity with an anti-colonial legacy via her father, her detractors in the military claim political descent from Burma's pre-colonial rulers. Contemporary historiography also retroactively conscripts thousands of foot-soldiers and cavalry who fought for various kings to overthrow the British, as the ancestors of a unified, homogeneous and nationalist Thatmadaw (army), thus inserting the current government into an uninterrupted thread of 'anti-colonialist struggle', which the proWestern Aung San Suu Kyi threatens to dishonour and disrupt. A key birthdate in this genealogy of the Thatmadaw is 1852, when the 'national races from all countries joined forces with Myanma Tatmadaw and unitedly fought the British' during the second Anglo-Burmese war, and a key site in this narrative is Shwedagon. ${ }^{69}$ In this rewrite of history, pre-colonial Burma becomes the 'First Myanmar Empire inhabited by united nationals called Myanmars', and today's anti-heroes - the students who spearheaded the protests of 1988 and 1990 - are eclipsed by yesterday's anti-colonial heroes, the students behind the 1920 boycott whose 'strong patriotism' is honoured on National Day. ${ }^{70}$ This political script underpins the SPDC's fashioning of a 'culture state' through the processes analysed by Houtman. To historians of Mon culture, these narratives are symptomatic of a centuries-long adoption and reproduction of Mon heritage as Burmese 'national culture'. ${ }^{71}$ The current regime has intensified this trend. Museographically at least, Shwedagon has become a palladium of a governing fiction, a shrine to the 'singular cultural essence' concocted by a military regime as the desideratum of a nation, the 'national unity' craved by all 'true' Myanmar citizens against the dissent and disunity of Suu Kyi's opposition movement. ${ }^{72}$

\section{Conclusion}

The colonial approach to Buddhist heritage in Burma developed episodically, from an initial intense stage of desecration and pillage of religious sites and an inverse sacralization of colonial space through the erection of military memorials, to an early twentieth-century recognition of the aesthetic value of maintaining particular religious sites and a belated attempt to intervene in this highly charged spiritual domain. Shwedagon's emergence as the highly politicized 'grounds for protest' of my title was pre-empted by a proliferation of new, Burmese additions to the site that violated European aesthetic norms and colonial heritage prescriptions. Works of merit, these shrines enhanced Shwedagon's spiritual potency and also served as vehicles of cultural protest in their circumvention of colonial prescriptions for temple conservation. In its fusion of the two notions of space posited by Partha Chatterjee in his analysis 
of indigenous resistance to colonialism - that of an inner, national cultural core and that of an outer, public sphere - the Shwedagon - a spiritual site that became a major arena for galvanizing and expressing public sentiment, and staging public protests - underscores the dynamic cross-weaving of these spheres. ${ }^{73}$

The Shwedagon's powerful symbolic capital is firmly anchored in its ability to galvanize national sentiment by synergizing secular and monastic interests, and in its potency as a field of Buddhist merit. Because Theravada Buddhism as practised in Burma requires regular contact with the realm of the rupakaya, the control of sacred sites allows ruling governments extraordinary power. Restricting access to a pagoda, by rendering if off-limits, as at times during British rule, or preventing individuals from attending the pagoda, as in the long-term house-arrest of Aung San Suu Kyi and members of the opposition in contemporary Myanmar, are all potent means of exercising control over the spiritual currency of merit.

In his nuanced study of Shwedagon as both an icon of identity and a site of protest, Craig Reynolds has shown how different groups have attempted to appropriate moments in its history for political advantage. Shwedagon oscillates between two dominant narratives: its formal and 'authentic' script as Burma's pre-eminent Buddhist pagoda, and an underlying, almost musical score vibrant with 'residues of meaning' that have accumulated at the monument and in memories. These latter cultural scripts, Reynolds shows, resist secular sculpting. Today, as in the past, Shwedagon remains a site where the 'nation may beg to differ with the state'. ${ }^{74}$

In his work on the monumental theatres for staging national imaginings, Benedict Anderson reads the modern European phenomenon of the tomb of the unknown soldier as both a mortuary for the passions that once simmered in the name of religion, and a baptismal to a new deity, the nation. The tomb honours the anonymous, and immortalizes the nation's soul as it makes relics of the newly dead who have sacrificed themselves for their country. In contemporary Myanmar, a reverse process holds true. The sacred reliquary chambers of Gotama Buddha become the avatar of a pure Burmese national soul, while merit is politicized. Despite the Thatmadaw's efforts to claim 'sacral continuity' with only the pre-colonial and anti-colonial moments of Shwedagon's history, they are powerless to quarantine these narratives from the pagoda's history of occupation. Here, the site itself offers sanctuary to different narratives of history.

\section{Notes}

* Research for this article was funded by a Harold White Fellowship at the National Library of Australia, a John T and Catherine D Macarthur Foundation Research and Writing Grant, and an ARC Postdoctoral Fellowship at the Centre for Cross-Cultural Research, Australian National University.

${ }^{1}$ Craig Reynolds, Icons of Identity as Sites of Protest: Burma and Thailand Compared, Taipei: Academic Sinica Program for Southeast Asian Studies (PROSEA) Research Paper No. 30, March 2000, p 10; U Win Pe, 'The Many Valued Significance of Shwedagon', in Elizabeth Moore, Hansjorg Mayer and 
U Win Pe (eds), Shwedagon: Golden Pagoda of Myanmar, Bangkok: River Books, Elephant House, 1999, pp 155-178, 177.

${ }^{2}$ For the purposes of this article, I use the term Myanmar to denote the military regime (now known as the State Peace and Development Council) which adopted that nomenclature in 1989. I use the term Burma to denote the country under British rule and as a contemporary geographic entity.

${ }^{3}$ George W Bird, Wanderings in Burma, London: Simpkin, Marshall, Hamilton, Kent \& Co, 1897, p 126.

${ }^{4}$ Aung Than, Shwedagon: The Sacred Shrine, Rangoon: Government Printing and Stationery, 1949.

5 Juliane Schober, 'A Tooth Relic and the Legitimation of Power', in Frank E Reynolds and John A Carbine (eds), The Life of Buddhism, Berkeley: University of California Press, 2000, pp 45-59.

${ }^{6}$ U Tun Aung Chain and U Thein Hlaing, Shwedagon, Rangoon: Universities Press, 1996, p vii. On the Mon, see Emmanuel Guillon, The Mons: A Civilization of Southeast Asia, trans. James V Di Crocco, Bangkok: The Siam Society, 1999, pp 236, 242.

7 Christmas Humphries, President of the Buddhist Society, London, cited in Aung Than, Shwedagon, p iii.

${ }^{8}$ Peter Harvey, 'Devotional Practices', in Peter Harvey (ed.), Buddhism, London and New York: Continuum, 2001, pp 130-134.

${ }^{9}$ Bird, Wanderings, p 145.

${ }^{10}$ Letter from Mrs Judson, Rangoon, quoted in John D Knowles, Life of Mrs Ann H. Judson, Late Missionary to Burmah, Philadelphia: American Sunday School Union, 1830, pp 88-90.

11 Bird, Wanderings, p 94.

12 Christopher Winter, Six Months in British Burmah: or, India beyond the Ganges in 1857, London: Richard Bentley, 1858, pp 31-32.

13 Rudyard Kipling, Barrack-Room Ballads and Other Verses, London: Methuen and Co., 1893, pp 50-54.

14 Th H Thomann, Pagan: Ein Jahrtausend Buddhistischer Tempelkunst, Stuttgart: Walter Seifert, 1923, p 112.

15 Ashley South, Mon Nationalism and Civil War in Burma: The Golden Sheldrake, London: Routledge Curzon, 2003, p 33; Guillon, The Mons, p 171.

16 Elizabeth Moore, 'Ritual Continuity and Stylistic Change in Pagoda Consecration and Renovation', paper presented at the Universities Historical Research Centre Conference, Yangon, 2000, p 5.

17 T H Biggs, The Shwedagon Pagoda, Rangoon: The Hanthawaddy Press, 1963 (first published in 1895), p 1. See also Reynolds, Icons of Identity, p 5.

18 Judson, quoted in Knowles, Life of Mrs Ann H. Judson, pp 88-90.

19 Ellen Corwin Cangi, Faded Splendour, Golden Past: Urban Images of Burma, Kuala Lumpur and New York: Oxford University Press, 1997; Judson, quoted in Knowles, Life of Mrs Ann H. Judson, pp 88-90.

20 J Butler, Sketch of the Service of the Madras European Regiment, 1839, pp 22ff, cited in B R Pearn, History of Rangoon, Rangoon: American Baptist Mission Press, 1939, p 128; J E Alexander, Travels from India to England, n.p., n.d., pp 18, 23; B Doveton, Reminiscences of the Burmese War in 1824-6, London, 1852, p 195.

21 Florence Maryatt, The Life and Letters of Captain Maryatt, vol. 2, New York: D Appleton, 1872, p 85.

22 Aung Than, Shwedagon, p 2.

${ }^{23}$ Ma Tin Yee, The Golden Shwedagon, Rangoon: Ma Khin Tint Publishing House, 1984, pp 26-28.

24 Cangi, Faded Splendour, p 79.

25 Myanmar National Archives 1/1 (A), Accession No. 3, File No. 3, 1853: S P Grant, Secretary to the Government of India, to Captain A P Phayre, 19 December 1853.

${ }^{26}$ Bernard Cohn, 'Representing Authority in Victorian India', in Terence Ranger and Eric Hobsbawm (eds), The Invention of Tradition, Cambridge: Cambridge University Press, 1994, pp 178-179.

27 Bird, Wanderings, p 152.

${ }^{28}$ Emanuel Sarkisyanz, Peacocks, Pagodas and Professor Hall: A Critique of the Persisting Use of Historiography as an Apology for British Empire-building in Burma, Athens, OH: Institute for International Studies, Papers in International Studies: Southeast Asia Series, Ohio University, 1972, p 20.

${ }^{29}$ E Hart, Picturesque Burma Past and Present, London: J M Dent and Co, 1897, pp 15-16.

${ }^{30}$ R B Graham, Photographic Illustrations of Mandalay and Upper Burmah Expeditionary Force, 1886-87, Birmingham: A Pumphrey, Photographic Publisher, 1887, plate 33.

31 I visited Mandalay in June 2004, and found the font still in situ and intact.

32 G Appleton, Buddhism in Burma, London: Longmans, 1943, p 37.

33 Thomann, Pagan, p 112.

34 Myanmar National Archives Series 1/1 (A), Accession No. 1429, File 11: 'Invitation from the Prince Minister to the King of Ava to The Chief Commissioner, British Burma', 5 February 1872.

35 Winter, Six Months, p 9; Graham, Photographic Illustrations, plate 35 (View on C Road); Kenneth G Orr, 'The Place of Anthropology among the Social Studies of Burma', Journal of the Burmese Research Society 34(pt 1), 1951, p 19. 
36 Aung Than, Shwedagon, p 9.

37 R Talbot Kelly, Burma Painted and Described, London: Allen and Charles Black, 1912, pp 252-253.

${ }^{38}$ Patrick Brantlinger, Rule of Darkness: British Literature and Imperialism, 1830-1914, Ithaca, NY: Cornell University Press, 1988, pp 230-232; Robert Young, Colonial Desire: Hybridity in Theory, Culture and Race, London: Routledge, 1999, p 178.

39 Hart, Picturesque Burma, p 1; Bird, Wanderings, p 126.

${ }^{40}$ Orr, 'The Place of Anthropology', p 19.

41 Aung Than, Shwedagon, p 12.

42 Taw Sein Ko, 'Custody of Pagodas at Pagan', Report of 1902-1903; Aung Than, Shwedagon, p 12; Taw Sein Ko, Report of the Archaeological Survey of Burma for the Years 1902 to 1903, Rangoon: Government Printing Press, 1903, p 1; V C Scott O'Connor, The Silken East, London: Hutchinson \& Co, 1904, pp 110-112, 115-116.

43 Kelly, Burma Painted, p 17.

${ }^{44}$ O'Connor, The Silken East, pp 120-123.

${ }^{45} \mathrm{H}$ Thirkell-White, A Civil Servant in Burma, London: Edward Arnold, 1913, pp 11-12.

46 Bird, Wanderings, p 156.

47 John Nisbet, Burma under British Rule-and Before, London: Archibald Constable \& Co Ltd, 1901, p 290; Thirkell-White, A Civil Servant in Burma, pp 64-65.

48 Bird, Wanderings, pp 156-157; George Scott Burma, A Handbook of Practical Commercial and Political Information, Alexander Morning, London, 1911 (Second Edition. First published 1906), p 342.

49 Thirkell-White, A Civil Servant in Burma, pp 64-65.

${ }^{50}$ Taw Sein Ko, Report of the Superintendent of the Archaeological Survey of Burma (hereafter RSASB), for the year ending 31 March 1910, p 3; Orr, 'The Place of Anthropology', pp 18-19.

51 Charles Duroiselle, RSASB, for the year ending 31 March 1921, pp 7-8.

52 Partha Chatterjee, The Nation and its Fragments: Colonial and Postcolonial Histories, Princeton: Princeton University Press, 1993, p 121.

53 Bird, Wanderings, p 156.

54 Thirkell-White, A Civil Servant in Burma, pp 11-12; Aung Than, Shwedagon, pp 1-2.

55 Myanmar National Archives. Government of Burma Police Department No. 168C-23, 6 February 1922; J S Furnivall, Maung Tin and Maung Hla Pe, 'Report of the Committee Appointed to Enquire into the Shwedagon Fracas', 14 January 1922.

56 Mikael Gravers, Nationalism as Political Paranoia in Burma: An Essay on the Historical Practice of Power, Copenhagen: Nordic Institute of Asian Studies, 1993, pp 25-26.

57 Than Htut, 'Two Songs', Myanmar Historical Research Journal 8, December 2001, pp 43, 45.

58 Myanmar National Archives, Yangon. Series 1.1 (A), Access No. 5982, File No. 732D(M) 39, 1939.

59 Gravers, Nationalism as Political Paranoia, p 41; Aung Than, Shwedagon, p 9.

60 Aung Than, Shwedagon, pp 2-3.

61 Aung San Suu Kyi, Freedom from Fear and Other Writings, London: Penguin, 1991, p 199.

${ }^{62}$ Monique Skidmore, Karaoke Fascism: Burma and the Politics of Fear, Durham, NC: Duke University Press, 2004, p 85.

63 'Patriarch Maha Theras', 'Ovadakathas Delivered to State Law and Order Restoration Council Chairman Senior General Saw Maung', Yangon: Religious Affairs Department Press, 1991, pp 1, 3.

${ }^{64}$ Christina Fink, Living Silence: Burma under Military Rule, Bangkok: White Lotus, 2001, p 218.

${ }^{65}$ Skidmore, Karaoke Fascism, pp 14-15.

66 Yee, Golden Shwedagon, pp 9-11.

67 'Promoters of Theravada Buddhism', The New Light of Myanmar, 6 May 1998.

${ }^{68}$ Gustaaf Houtman, Mental Culture in Burmese Crisis Politics: Aung San Suu Kyi and the National League for Democracy, Study of Languages and Cultures of Asia and Africa Monograph Series, no. 33, Tokyo University, 1999; Houtman, 'Remaking Myanmar and Human Origins', Anthropology Today 15(4), 1999, pp 13-19; Schober, 'A Tooth Relic', pp 45-59.

69 'Anti-Colonialist Struggle', http//www.myanmar.com/e-index/Union/colonia.html (accessed 1 May 2001); 'Efforts for the Flourishing and Propagation of Union Spirit and National Solidarity', http:// www.myanmar.com/e-index/Union/efforts.html (accessed 1 May 2001).

70 Tekkatho Tin Kha, 'Inborn National Duty', The New Light of Myanmar, 24 November 1997, p 5.

71 South, Mon Nationalism and Civil War, pp 31-33.

72 Gravers, Nationalism as Political Paranoia, p 240.

73 Chatterjee, Nation and its Fragments, p 121.

74 Reynolds, Icons of Identity, p 10. 